\title{
Theological poverty of churches in the developing world: Its causes and effects
}

\author{
Author: \\ Jae-Buhm Hwang ${ }^{1}$ \\ Affiliation: \\ ${ }^{1}$ Department of Christian \\ Studies, Keimyung \\ University, South Korea \\ Correspondence to: \\ Jae-Buhm Hwang \\ email: \\ jbhwang@kmu.ac.kr \\ Postal address: \\ College of Humanities, \\ Keimyung University, \\ Dalseogu, Daegu 704-701, \\ South Korea

\section{Dates:} \\ Received: 21 Apr. 2010 \\ Accepted: 29 Nov. 2010 \\ Published: 11 Apr. 2011 \\ How to cite this article: \\ Hwang, J-B., 2011, \\ 'Theological poverty \\ of churches in the \\ developing world: Its \\ causes and effects', \\ HTS Teologiese Studies/ \\ Theological Studies 67(3), \\ Art. \#833, 7 pages. DOI: \\ 10.4102/hts.v67i3.833
}

(C) 2011. The Authors. Licensee: OpenJournals Publishing. This work is licensed under the Creative Commons Attribution License.
By and large, the non Protestant churches from the developing world rarely have a creative theology that is unique to their own cultures and religiosity. It was my hypothesis that the theological barrenness of churches from the developing world is partly as a result of the antiintellectualist legacy of the past missions from the developed world. This legacy was fostered by the strong paternalism of these past missions on the one hand and on the other, by their revivalist conversionism. The anti-intellectual legacy has brought two notable results to the missionised churches from the developing world: their profound dependency on theologies from the developed world and their resulting theological poverty, both interdependent elements.

\section{Introduction}

By and large, the Protestant churches of the developing world, which have been largely missionised in past centuries by Protestant missionaries from the developed world, have failed to develop a creative theology that is unique to their own cultures and religiosity. Since the 1960s, the churches of the developing world have begun to think critically about their faith, which had been articulated predominantly in a way that speaks to the developed world. They then realised that, having had little theological creativity, they had largely been held captive by theologies from the developed world. Acknowledging that Christian theology in India reflected 'an almost entirely Western type of thought and language', theologians in India lamented that 'they have not yet produced official doctrinal statements which express the Christian faith in a distinctively Indian way' (Boyd 1969:207). This is also true of the Japanese Protestant churches, which have experienced 'Germanic captivity of Japanese theology' (Drummond 1994:249). It is also undeniable that the Korean Protestant churches, having more than 10 million adherents, have not yet produced official doctrinal statements that are distinctively different from the ones from the developed world. ${ }^{1}$ This may also be the case for an African theology. Thus Kofi AppiahKubi (2002) claims that:

our question must not be what Karl Barth, Karl Rahner, or any other Karl has to say, but rather what God would have us do in our living concrete condition. For too long African Christian theologians and scholars have been preoccupied with what missionary A or theologian B or scholar C has told us about God and the Lord Jesus Christ.

(Aguilar 2002:309)

It is arguably Choan-Seng Song (1977) who has most deeply grieved over the captivity of Asian theologies by the developed world:

In short, Western mission agencies have not been satisfied with the role of planting and giving water to Christian communities in the non-Western lands. They have shaped these Christian communities, moulded them and forced them to grow into 'White' churches in 'Black' Africa or 'Yellow' Asia'.

(Song 1977:7)

According to Morimoto (2009:76), Song 'has expressed strong antipathy to Western theology and at times advocates that Asian theologians should discard the entire two-millennium history of theology.' These laments and claims of Asian and African theologians may be enough reason to say that African and Asian Christian theologies scarcely have theological originalities that differ from those of the developed world. What, then, are the causes of this kind of theological poverty of the mission churches?

It is my hypothesis that the theological barrenness of churches of the developing world is partly as a result of the anti-intellectualist legacy of the past missions from the developed world. I identified two outstanding causes of the anti-intellectualism that these past missions entailed:

1.The two relatively liberal Korean Presbyterian churches (Kijang and Tonghap) have their own confessions of faith adopted in 1972 1986 and 2002 respectively, which were articulated mainly in the way of the developed world. The remaining conservative Korean Presbyterian churches and other denomina confes 'he. At present, the sth') clause, he descended into hell); the so-called Twelve Articles of Faith, which is largely very conservative; the Westminster Confession of Faith and the Westminster Shorter Catechism. Thus, it would not be unfair to say that Korean Protestant theology in general is still held in captivity by the 19th century missionary theology, which is puritanical and fundamentalist in tone. 
paternalism and revivalist conversionism. After explaining these two causes, I examined how the anti-intellectualism of these past missions prompted the mission churches to experience theological paucity. There has been almost no extensive study of the reasons for the theological deficiency of churches of the developing world; this is especially the case for Asian churches. For instance, both Song and K. Koyama, perhaps the two most influential Asian theologians for more than a generation, have seldom substantially dealt with this problem, whilst only emphasising that Asian theologies have to be freed from their captivity by the developed world. This article, will fill this gap, facilitating further discussions of this fundamental theological problem.

Here, acknowledgment has to be made for some original theologies that churches of the developing world have produced, notably liberation theologies, including Korean Minjung theology. Although they have some creative elements, they nevertheless have seldom been reflected in the official confessions of faith of the mainline churches of the developing world. Therefore, they were not considered in this article. Acknowledgment is further to be made also for the past missionaries from the developed world, who brought Jesus Christ to Asia and Africa. Through them tens of millions of Asians and Africans have found salvation, individual as well as social; with the saving love of Christ both the missionaries and their successors have changed the course of the world history towards a more communicable, tolerable and viable world. But this should not be the last words of the missionaries' Asian or African successors, who are obliged to develop the legacies of the missionaries, especially by critically assessing them. This may justify my present study, which is critical to both the missionaries and their Asian or African successors.

\section{The paternalistic cause of the anti- intellectualism of the past missions}

The developed world's missionaries' widespread paternalism was one important cause of the anti-intellectualism and theological deficiency of the missionised churches. A paternalistic mission takes place in a one-way and asymmetrical (master-slave) relationship between the missionaries and their native converts. It seldom has an 'I and Thou' element, which is essential for intellectual and spiritual growth of both parties. William Kornfield (1991) claims:

Paternalism creates dependency. It denies the wholeness of the individual and ultimately leads to his or her bondage and suppression. There can be no genuine reciprocity between individuals or groups when one of them treats the other like a child.

(Kornfield 1991:230)

A paternalistic mission may have a philanthropic and Christian nature to start with, but in the long run, ends up bringing about an impersonal 'I and It' relationship between the missionaries and their native converts that results in profound intellectual passivity for the latter. Here, it is necessary to observe that the paternalism of the past missions from the developed world was not a historical accident, but a necessary expression of the past colonialism of the developed world, which saw the developing world as inferior and immature, an object to educate, civilise and regenerate.

The past missionaries from the developed world came to African and Asian countries with not only the Gospel, but a kind of 'superiority complex' toward the supposedly heathen and backward people. ${ }^{2}$ In the words of Hendrik Craemer, these past missionaries had 'spiritual imperialism', which included the conviction that they could dispose of the destiny of the world, because the absorption of the Eastern by the Western world appeared to come inevitably' (Kraemer 1947:36). With that kind of 'spiritual imperialism' or 'Christian triumphalism' (Hutchison 1989:169), the missionaries could not help but have a colonialist worldview, perceiving the native people as backward, inferior and superstitious. This kind of a colonialist perception logically led to the missionaries being paternalistic and this was even strengthened by their fundraising system. By emphasising how backward and superstitious the natives were, the missionaries intended to impress their supporters at home to get all the more financial and psychological supports from them.

The colonialism of the developed world included the dualist world-view that the developed world is good, whilst the native is bad. With this kind of a dualist world-view, a past missionary from the developed world led his native converts to take from him and hindered them from giving to him. It follows that the native Christians could have little chance to think intellectually about what they had, whilst being preoccupied with imitating their missionaries. It is clear that this process necessarily brought about anti-intellectualism and non-creativity for the native Christians. An African missionary vividly depicts how the process unfolded:

We force the African continually to take from us and prevent him from giving to us in his own rich way. We deny Africa its own unique creativeness ... The missionary, either in the van or close behind, came to abolish the black man's spirits, give him a new sense of sin, do away with his practice of religion, as base superstitions, and win him over to a new and superior white god. The rejection of Africa in all dimensions was as complete as it could possibly be ... I am old enough to remember the enormous hush that fell over Africa in the wake of the coming of European man.

(Van der Post 1955:22, 54-55, as cited in Bridston 1965:42)

This kind of a colonialist thrust is usually based on the missionaries' conviction that they have the right doctrine and religion, whilst all that the natives have is pagan, backward and superstitious. As a result, the missionaries were busy with only imposing their own right belief and practices to their native converts and not paying due attention to what the latter had. Rev. Michael Hollis (1962), sometime Bishop

2.Accordingly, an Indian Christian leader cried at a decennial mission conference of the Presbyterian Church in the U.S. 'You must decide now what kind of mission Preu ar en you are going to send out; they must go out in the spirit of our Lord to serve the people and to be friends with them; there should be no superiority complex' (Board of Foreign Missions of PC [USA] 1932:69). 
in Madras, India, well depicts what is at issue here:

Broadly speaking, the mission pattern has been too much concerned to ensure that Indian Christians accepted the right formulations of belief, as developed in the West, and followed the right patterns of behaviour, again largely Western expressions of what was believed to be the law of God, within the framework of the particular Western ecclesiastical order which the mission approved. Greater freedom, greater readiness to allow God to deal with men's mistakes, greater belief in the present reality of the Holy Spirit might well have led to the appearance of a more responsible, more adventurous, more truly Indian and more truly Christian Church.

(Hollis 1962:36)

It is also clear that, although it was established in a humanitarian way, the missionaries' paternalistic authority was something mystified and to be feared and that it was therefore not so conducive to the natives' community and leadership building. In his survey of the Batak Church in Indonesia in 1938, a missionary well describes the problem here:

The mission and the missionary hold a place of authority in the Batak Church. The high degree of centralization in the organization of the Mission has resulted in its playing a paternalistic, if not a dominating part, in the life of the Christian community ... A large degree of authority is also held by the missionaries who preside over the five districts of the Church. While the power of the Mission is exercised with caution and consideration and while the wisdom and Christian spirit of the missionaries are of a high order, the position is one of danger for the solidarity of the Church and the growth of Batak leadership.

(Bridston 1965:69)

The missionaries surely needed many paternalistic institutions to do their various mission works; this was even necessary to impress their home supporters and receive all the more support from them, even if this mechanism often ruined their noble purposes and achievements. ${ }^{3}$ However, once a mission organisation was successful, it achieved great power and authority, which even strengthened the colonialist world-view on the part of the native Christians.

The past missions from the developed world often maintained paternalistic and anti-intellectualist education policies toward the native Christians. One of these policies was that the native clergy should be less educated than the missionaries. ${ }^{4}$ In some instances, there was even 'the passionate plea that the 'native agents' of the Church should be kept away from the English language' (Neill 1962:6) so that they might not know what the English-speaking missionaries knew. Because of this kind of negative measures for the natives' education,

3. Hudson Taylor, the famous founder of the China Inland Mission, knew the evil of this vicious mechanism and wanted to get as little support from home as he could. He said: 'To substitute medicine from the preaching of the Gospel would be a profound mistake. If we put schools for education in the place of spiritual power to change the heart, it will be a profound mistake' (Taylor 1911:407).

4.The American Presbyterian missionaries to Korea in 1896 had a policy that the educational level of their Korean native agents should be higher than that of average Koreans, but still below than that of the missionaries (Reynolds 1896:199201). According to Philip Curtin (1964:425-426 as quoted in Beidelman 1982:164), the native agents were also dictated to be paid less than the missionaries. In the case of Korea, this policy was even spiritualised. Consequently, a mission policy set by the American Presbyterian missionaries for Korean Christians says: 'It shall be definitely understood that the salaries of native agents are not salaries in the sense of payment for the work done, but rather a providing them with means of support so that they may be able to give their full time to the work to which they believe they have been called' (Clark 1930:80). even the conscientious missionaries themselves could not encourage the native Christian leaders to keep on studying and developing their creative ideas.

A paternalistic mission is reported to be dangerous, even without the explicit colonialist implication that was prevalent in the past. Recently, a leader of a North American mission agency said:

Leaders become preoccupied with raising North American funds. On a trip I took to India, I was overwhelmed by the many church leaders who 'worked' me for a dollar connection. Such a ministry orientation inevitably weakens faith, corrupts pure motives, and compromises leadership integrity. Also, leaders who can't get connected to the pipeline become demoralized.

(McQuilkin 1999:57)

This claim reveals that a paternalistic mission causes native leaders to be preoccupied with foreign resources, eventually deepening their financial and theological dependency; it is a vicious cycle.

Furthermore, seemingly natural and predictable barriers between the missionaries and their native converts led both groups to be anti-intellectualist. Firstly, the language barrier between the two very different parties greatly hindered both of them from having intellectual dialogues. Secondly, the missionary was an authority figure to the native converts, especially in religious matters and it was surely very hard for them to question what they had been taught by the missionary. Thirdly, for the natives, Christianity was a completely new religion, tightly wrapped in the languages and cultures of the developed world and difficult to decipher. These natural obstacles might have caused the missionaries to take a paternalistic and anti-intellectual measure toward the natives. But this circumstance, in turn, caused the natives' anti-intellectualism to grow even deeper.

\section{The conversionist element of the anti-intellectualism of the past missions}

The majority of the modern missionaries from the developed world (especially American missionaries), were largely from various kinds of revivalist movements and usually had a threefold anti-intellectualist attitude:

- appealing to conversion experience

- doing away with past Christian traditions

- preoccupation with simplistic Biblical and dogmatic knowledge.

Here, it is to be noted that there was far more to the missions from the developed world in Asia and Africa than conversions and that all conversions did not bring about antiintellectualism. What is at issue here is rather that a revivalist or Pentecostal orientation has an inherent tendency towards anti-intellectualism. The anti-intellectualist orientation of revivalism or Pentecostalism is not merely an old story, but is still prevalent in the United States and all over the world, as an American Evangelical theologian speaks out: 
Endemic to Pentecostalism is a profoundly anti-intellectual ethos. It is manifested in a deep suspicion of scholars and educators and especially biblical scholars and theologians ... Not all Pentecostals are anti-intellectual or revel in incoherence. But a deep antipathy to critical rationality applied to theology is a hallmark of the movement. Too often spiritual abuse in the form of shame is directed at those, especially young people, who dare to question the teachings of highly placed Pentecostal ministers and evangelists.

(Olson 2006:27)

Talking about 'the anti-intellectual ethos found in Pentecostalism,' Lewis (2008) insists that:

whereas the emphasis has been keenly observed for Pentecostalism, it should be also noted that anti-intellectualism and related issues are considered a problem of Evangelicalism as a whole, although arguably to a lesser degree.

(Lewis 2008:72)

Thus, it is safe to say that Evangelicalism in general and Pentecostalism or revivalism in particular have continuously kept and fostered an intrinsic anti-intellectualism.

It is of utmost importance that the modern revivalist movements themselves, which supplied the majority of the missionaries, especially had an anti-intellectualist bent, because they were only preoccupied with the gaining of converts, despising the understanding of traditional Christian truths. There was another important factor that facilitated the revivalist, conversionist and antiintellectualist tendency of modern Protestantism, namely denominationalism. As a matter of fact, the modern world saw unprecedented numbers of Protestant denominations that were brutally competing with one another to gain as many converts as possible. 'In a society so mobile and fluid, the basic purpose of the denominations, to which all other purposes and commitments were subordinated, was that of gaining converts' (Hofstadter 1963:84).

Gaining converts is a predominantly pragmatic and quantitative measure, which is often opposed to, or has little to do with, the qualitative way of understanding traditional Christian truth. Learning and understanding traditional or apostolic Christian truth had been one of the defining aspects of Christianity in general and Reformation tradition in particular. That was greatly weakened in modern American Protestantism, however, as within that tradition both the lay people and the clergy in general were preoccupied with gaining converts. R. Hofstadter (1963) said:

As Dwight L. Moody once put it, 'It makes no difference how you get a man to God, provided you get him there' ... For the layman the pragmatic test in religion was the experience of conversion; for the clergyman, it was the ability to induce this experience. The minister's success in winning souls was taken as the decisive evidence that he preached the truth.

(Hofstadter 1963:85)

James Barr (1984:153) also said: 'Modern evangelicalism is above all a missionary religion: it is organized and equipped to convert and the fact and experience of conversion is central to its thinking and experience.' Because it aimed at a pragmatic purpose, inducing as many conversions as possible, modern evangelicalism with a revivalist bent inevitably lacked some necessary intellectual discipline and caused the converts to be both anti-intellectualist and anti-traditional. Hence, the missionaries as the product of those revivalist movements could not help being anti-intellectualist.

Gaining converts was even more important in the mission fields, given that it was the most important test of the missionaries; their de-facto mission was gaining as many converts as possible. This explains why almost all of the mission reports were full of conversion stories and statistical numbers of converts, which was believed to be the most appealing news to the supporters at home. What the missionaries used in order to induce all the more conversions in a given time was a revivalist simplistic message that they had learned from their former teachers at home; God's judgment on the secular and the heathen:

Simple people were brought back to faith with simple ideas, voiced by forceful preachers who were capable of getting away from the complexities and pressing upon them the simplest alternatives: the choice of heaven or hell.

(Hofstadter 1963:84)

A mission scholar also said: 'Pietistic missionaries confined themselves to preaching to individuals whom they sought to impress with the eternal judgement of God' (Bavinck 1948:27 as cited in Bridston 1965:44). This simplistic and negative rhetoric stressing God's judgement on the secular and heathen might be somehow useful to induce the natives' conversions, but harmful for them to develop their own thought in a creative way.

The missionaries with a revivalist and conversionist background were turning their backs on the 'universal and apostolic' church tradition, whilst at the same time being obsessed with simplistic Bible studies, another important factor of their anti-intellectualism:

The denominations [in the modern America] were trying to win to church allegiance a public which, for whatever reason, had not been held by the traditional sanctions of religion and which had lost touch both with liturgical forms and with elaborate creeds ... Revivalism succeeded where traditionalism had failed.

(Hofstadter 1963:84)

What the missionaries emphasised in the place of traditional liturgies and creeds was simplistic Bible studies that brought about a strong Biblicism for the part of the native Christians. The missionaries' view of the Bible was usually pietistic, revivalist and almost fundamentalist. ${ }^{5}$ An American missionary in Korea said:

The Bible was the chief textbook, though use was made of commentaries and other helps, as far as they were available ... Much attention was given to rehearsing Scripture stories and to catechetical instruction [using the Westminster Shorter Catechism] ... The Bible is made the basis of all the work, and

5.As the famous mission scholar Arthur J. Brown (1921:540) says: 'The typical missionary of the first quarter century after the opening of the country [Korea] was a man of the Puritan type. He kept the Sabbath as our New England forefathers did a century ago. He looked upon dancing smoking and card-playing as sins in which a century ago. He looked upon dancing, smoking and card-playing as sins in which no true follower of Christ should indulge. In theology and biblical criticism he was strongly conservative and he held as a vital truth the premillenarian view of the second coming of Christ. The higher criticism and liberal theology were deemed dangerous heresies. In most of the evangelical churches of America and Great Britain, conservatives and evangelical liberals have learned to live together in peace, but in Korea the evangelical liberal, whose interpretation of the Bible differs from the commonly accepted one, sometimes has a rough road to travel.' 
the aim is so to fill the minds of the people with it that it will control conduct. The Bible is the only authoritative guide to answer questions.

(Clark 1937:34-35)

Given that the Bible was that much esteemed and the traditional liturgies and creeds seldom taken seriously, it was almost impossible for the native Christians, who had little knowledge of the Bible, to pose critical questions about biblical texts. This anti-intellectualistic process naturally caused fledgling Korean Christians to embrace a strong Biblicism that was decidedly anti-intellectualistic.

The real danger in emphasising a simplistic Bible study, of course, was that studying the Bible in this fashion was not a way of finding and deepening Christian truth, but only an instrument to achieve another practical and commercial goal, namely to gain converts. An American missionary in Korea demonstrated what is at issue here, when he said:

It seems to be a fact, and would seem to be a scientific fact worthy of careful study, that around the world the Bible-centered churches are crowded with worshippers and multitudes of people in them are getting 'changed,' or, as the conservatives say, 'converted, regenerated,' while the so-called 'liberal' churches are not getting those results.

(Clark 1937:276)

Here, the missionaries tended to have a distorted logic of cause and effect, assuming that teaching the Bible necessarily induces conversion. It may induce conversion in some cases, whilst in others it may not. But, because they took the distorted logic for granted, they excessively emphasised simplistic Bible studies and caused the native Christians to have an anti-intellectualistic Biblicism. Because of that distorted logic, a Korean Christian minister was trained to be 'a Holy Ghost man', meaning that what mattered to them was not deep theological knowledge, but pietistic enthusiasm for evangelism (Reynolds 1896:199-201). In fact, the Korean divinity students' theological education itself in the first half of the last century was geared towards the experience of conversion and evangelism, for which they had to focus on simplistic Bible studies.

The revivalist and Biblicist position on the Holy Scriptures created an unusual Biblicism in Korea that had a notably durable anti-intellectualist and noncreative bent through the 20th century. As a result of this Biblicism that still prevailed in the Korean Protestants' hearts and brains, no Korean Christian dared to critically study the Holy Scriptures until the 1960s. Even today, the majority of Korean Protestants take the inerrancy of the Bible for granted and have little creative ideas about its actual contents. It is no wonder that Asian theologians, Korean theologians in particular, are still largely 'held in the captivity of the developed world'.

\section{Some negative results of the anti- intellectualism of the past missions Theological poverty of the churches from the developing world}

The anti-intellectual tradition that stems from the paternalistic, revivalist-conversionist and Biblicist elements of the past missions from the developed world has had a number of baleful effects on the missionised churches in the developing world. Firstly, of course, has been their profound dependency on theologies of the developed world and their resulting theological poverty, both interdependent elements.

The paternalistic, revivalist-conversionist and Biblicist thrust of the missionaries made it nearly impossible for native converts to take their own culture and religiosity seriously:

Missionaries with pietistic backgrounds are prepared to suspect that everything the local people do is bad and that therefore, in order to save them, they must pull them out and set up another kind of life opposed to the original one.

(Bridston 1965:45)

This situation has given rise to a vicious cycle on the part of the native Christians: contempt of their own culture and religiosity and idolising all things from the developed world, not only Christianity, but civilisation from the developed world.

What the native theologians have done instead of reflecting on and theologising about their cultures and religiosity is only idolising and imitating (and partly pirating) theology and culture from the developed world. As the Rev. David Chellappa, a bishop of the Church of South India notes: 'Instead of struggling to find a theology that is at once Indian and Christian, the [Indian] theological students bury themselves in the writings of Western theologians' (Bridston 1965:62). For the majority of Korean theological students, this is even more the case, because they have been educated to be Biblicists and fundamentalists practically, if not theoretically. Park, (1964), one of the most influential Korean theologians proudly says:

My desire is to transmit to the new generations the very theology that the Western missionaries in Korea gave us eighty years ago. What I want to do is never daring to write a new theology.

(Park 1964:i)

It is no wonder that almost no Asian churches have yet produced a theology that is both Christian and distinctively Asian.

Therefore, having had virtually no theological freedom, the majority of theologians from the developing world have been preoccupied with habitually imitating the theology and cultural forms of the developed world. This explains why mission churches in general scarcely have distinctive original architectural, artistic and theological productions. Those coming from the developed world may be shocked to find out that the majority of Asian church buildings are monolithic and superficial imitations of the ones in the developed world. This is also true of the liturgies, creeds and theologies of the mission churches. Accordingly, I fully agree with Rev. K. Bridston (1965) when he says:

The churches that have been resulted from the missionary activities of the Western churches have markedly undistinguished in theological creativity. They have been barren because they have not arisen from the 'ground' itself.

(Bridston 1965:61)

There has been an even more tragic element stemming from the native theologians' 'habit of imitation', namely 
the deprivation of their creativity. Imitation seems to be a relatively harmless phenomenon, but when it persists, it hurts the intellectual and moral integrity that is essential for the creative act. Frank Lloyd Wright, the famous architect, so poignantly pointed out what is at issue here when he wrote:

Half-baked, imitative designs (fictitious semblances) pretentiously put forward in the name of a movement or a cause ... endanger the cause, weaken the efficiency of genuine work, for the time being at least; lower the standard of artistic integrity permanently; demoralize all values artistically; until utter prostitution results.

(Kaufman \& Raeburn 1960:184 as cited in Bridston 1965:60-61)

The anti-intellectual elements based on the paternalistic, conversionist and Biblicist tendencies of the past missions from the developed world have caused the theologians from the developing world to imitate theologies of the developed world, depriving them of theological creativity. What, then, should they do? They should listen to themselves, instead of only imitating a foreign theology, however great it may be. It is instructive that even a theology of the developed world, for instance, Lutheran or Reformed orthodoxy, was generally based on the 17th century Scholasticism, which was a distinctively European thinking-paradigm of the time. Therefore, it might be very conducive for theologians from the developing world to think and do theology the way their own native people do.

\section{For a creative theology of churches of the developing world}

Theologians from the developing world might stop only imitating the theologies of the developed world, whilst sincerely studying their own theological thoughts and thinking-patterns:

Creativity requires self-knowledge. Profound and yet subtle, exacting yet questioning. This is the real job of mentors who would nourish creativity-to help the student hear his own voice, see his own soul. This is why creativity is so closely linked to self-esteem, and why it can lead to real breakthroughs for students who suddenly find the source inside themselves. No other subject is located so much in the inner libraries of memory, dream, and reflection. Creativity realized and enacted is a kind of dialogue of self-reflection with the outside world.

(Kay 1998:1)

For a theologian from the developing world, however, selfknowledge means a double reflection: on their own cultures, on the one hand and on Christian tradition of two thousand years, on the other. This may be why John Mbiti does not stress only African sources, but also historical Christian tradition. ${ }^{6}$

How, then, have some creative African or Asian theologians regarded those two theological sources? Firstly, various liberation theologians have taken their socio-political

6.According to V.G. Ezigbo (2008:53), John Mbiti (1972:51-62) spoke of 'the four sources or "pillars" of African theology: the Bible, the theological tradition of the older (Western) churches, traditional African worldview and the living experience of the churches in Africa.' The last two elements, however, may be roughly categorised as one African (native) source. Thus, the fundamental theological sources for a creative African or Asian theology may be summed up as three: the Bible, Christian tradition and native sources, including a salvation experience. situations seriously as their native sources. Secondly, Asian contextual theologians, for instance both C.S. Song and K. Koyama, the two most important Asian theologians, also utilise their Asian sources. Yet, whilst making use of their own Asian or African native sources, both liberation and contextual theologians usually end up disregarding their historical Christian traditions, especially the ones from the developed world. This is especially true of Song, who wants to abandon, not only the past paternalistic legacies of missionaries from the developed world, but the whole history of Christianity. But can theologians from the developing world do theology as Song wants? They may, yet what they produce may cause confusion and disunity, given that their theologies may be different from one another, having no integrative historical references.

\section{Conclusion}

The way for a theologian from the developing world to do a creative theology is even narrower than that for one from the developed world to do so. The former should create a theology that is not simply contextually relevant, but historically correct, that may give a sense of stability and integrity to African or Asian Christians, who have been too young to have historical and apostolic norms and might eventually become confused otherwise.

\section{Acknowledgement}

This article was made possible by the Bisa Research Grant of Keimyung University in Daegu, South Korea.

\section{References}

Aguilar, M.I., 2002, 'Postcolonial African Theology in Kabsele Lumbala', Theological Studies 63(2), 302-323.

Barr, J., 1984, Beyond Fundamentalism, The Westminster Press, Philadelphia.

Bavinck, J.H., 1948, The Impact of Christianity on the Non-Christian World, Eerdmans, Grand Rapids.

Board of Foreign Missions of PC(USA), 1932, The Lakeville Report: Report of the Decennial Conference on Missionary Policies and Methods, Board of Foreign Missions of PC(USA), New York.

Beidelman, T.O., 1982, Colonial Evangelism: A Socio-Historical Study of an East African Mission at the Grassroots, Indiana University Press, Bloomington.

Boyd, R., 1969, An Introduction to Indian Christian Theology, The Christian Literature Society, Madras.

Bridston, K., 1965, Mission Myth and Reality, Friendship Press, New York.

Brown, A.J., 1921, The Mastery of the Far East: The Story of Korea's Transformation and Japan's Rise to Supremacy in the Orient, Charles Scribner's Sons, New York.

Clark, C.A., 1930, The Korean Church and the Nevius Methods, Fleming H. Revell Company, New York.

Clark, C.A., 1937, The Nevius Plan for Mission Work, Christian Literature Society, Seoul. Curtin, P., 1964, The Image of Africa, University of Wisconsin Press, Madison.

Drummond, R.H., 1994, 'A New History of Japanese Theology', Mission Studies XI2(22), 243-253. doi:0.1163/157338394X00179

Ezigbo, V.G., 2008, 'Rethinking the Sources of African Contextual Christology', Journal of Theology for Southern Africa 132, 53-70.

Hofstadter, R., 1963, Anti-Intellectualism in American Life, Alfred A. Knopf, New York. Hollis, M., 1962, Paternalism and the Church, Oxford University Press, London.

Hutchison, W.R., 1989, 'Americans in World Mission: Revision and Realignment', in D.W. Lotz (ed.), Altered Landscapes: Christianity in America, 1935-1985, 155-170, Eerdmans, Grand Rapids.

Kaufman, E. \& Raeburn, B. (eds.), 1960, Frank Lloyd Wright: Writings and Buildings, Horizon Press, New York.

Kay, S., 1998, 'Curriculum and the Creative Process: Contributions in Memory of A. Harry Passow', Roeper Review 21(1), 5-13. doi:10.1080/02783199809553919 
Kornfield, W., 1991, 'What Hath Our Western Money and Our Western Gospel Wrought?', Evangelical Missions Quarterly 27(3), 230-236.

Kraemer, H., 1947, The Christian Message in a Non-Christian World, International Missionary Council, New York and London.

Lewis, P.W., 2008, 'Why Have Scholars Left Classical Pentecostal Denominations?', Asian Journal of Pentecostal Studies 11(1-2), 69-86.

Mbiti, J.S., 1972, 'Some African Concepts of Christology', in G.F. Vicedom (ed.), Christ and the Younger Churches, pp. 51-62, SPCK, London.

McQuilkin, R., 1999, 'Stop Sending Money! Breaking the cycle of missions dependency', Christianity Today 43(3), 57.

Morimoto, A., 2009, 'Contextualised and cumulative: tradition, orthodoxy and identity from the perspective of Asian theology', Studies in World Christianity 15(1), 65-80. doi:10.3366/E1354990109000355
Neill, S., 1962, Christian Faith and Other Faiths, Oxford University Press, London. Park, H.N., 1964, Gyo-eui shinhak [Dogmatic Theology], vol. I, Posoo Shinhak Seojeok Kanhaenghoe, Seoul.

Roger, O., 2006, 'Pentecostalism's Dark Side', Christian Century 123(5), 27-30.

Reynolds, W.D., 1896, 'The Native Ministry', The Korean Repository (May), 199-201.

Song, C.S., 1977, Christian Mission in Reconstruction: An Asian Analysis, Orbis Books, New York.

Taylor, H., 1911, Hudson Taylor in Early Years, Morgan and Scott Ltd., London.

Van der Post, L., 1955, Dark Eye in Africa, Morrow, New York. 